\title{
S. Pietrini, L'insegnamento del diritto penale nei libri Institutionum, Edizioni Scientifiche Italiane, Napoli 2012, 174 strony
}

Badania nad rzymskim prawem karnym przeżywają w ostatnim czasie swoisty renesans, nie tylko w przypadku naukowców polskich, ale nurt ten jest przede wszystkim szczególnie silny na zachodzie Europy ${ }^{1}$. Nie ulega wątpliwości, iż na ten stan rzeczy ma wpływ zmiana myślenia o rzymskim prawie karnym, postrzeganym już nie jako drugorzędny obszar badawczy, na co prawdopodobnie przez długi czas rzutował pogląd Th. Mommsena oraz F. Carrary o Rzymianach - olbrzymach w zakresie prawa cywilnego i karłach w stosunku do ius criminale ${ }^{2}$. Romaniści nie tylko poszukują korzeni współczesnych rozwiązań prawnokarnych ${ }^{3}$, ale także starają się w ujęciu monograficznym przedstawić konkretne przestępstwo ${ }^{4}$. Brakuje jednak prac, które mogłyby przybliżyć problematykę nauczania prawa karnego w starożytnym Rzymie. Tę lukę stara się częściowo wypełnić - chociażby z uwagi na zakres chronologiczny - recenzowana monografia.

Właściwą problematykę Autorka poprzedziła kilkoma spostrzeżeniami o charakterze ogólnym (Osservazioni intoduttive, s. 11-21), które nie spełniają roli tradycyjnego wstępu w monografiach. Stefania Pietrini podniosła, iż znajomość prawa karego nie była obca jurystom rzymskim, a na dowód tego przytoczyła kilka nazwisk wraz z dziełami, jakie zostały przez nich napisane (m.in. Ulpian, Saturninus, Mecianus czy Callistratus, por. s. 12-14). Co więcej, Autorka podniosła, iż znajomość prawa karnego nie była rozpowszechniona wśród kursów dydaktycznych w starożytnym Rzymie, co z kolei związane było z tym, iż podstawę nauczania prawa stanowiło ius privatum i dlatego nie dziwi w tym kontekście milczenie Gaiusa w jego Institutiones o prawie karnym czy też procesie karnym (s. 18-19). Tym bardziej trafne wydaje się podzielenie przez S. Pietrini obecnego w literaturze przedmiotu poglądu (V. Giuffré) o mniejszej atrakcyjności prawa karnego w stosunku do regulacji prywatnoprawnych (por. s. 16-18). Wiązało się to przede wszystkim z węższymi możli-

1 Tytułem przykładu można wskazać: J. E. Gaughan, Murder Was Not a Crime. Homicide and Power in the Roman Republic, Austin 2010; Sacertà e repressione criminale in Roma arcaica, red. L. Garofalo, Napoli 2013; K. Amielańczyk, Crimina legitima w rzymskim prawie publicznym, Lublin 2013.

2 Por. L. Garofalo, Pojęcie i żywotność prawa karnego, "Zeszysty Prawnicze” [UKSW] 2003, 3.1, s. 7-8.

3 Zob. K. Amielańczyk, Czy kontratyp obrony koniecznej ma rzymska tradycje? W poszukiwaniu przesłanek dopuszczalności prawa do samoobrony w rzymskim prawie karnym, [w:] Quid leges sine moribus? Studia nad prawem rzymskim dedykowane Profesorowi Markowi Kuryłowiczowi w 65. rocznice urodzin oraz 40-lecie pracy naukowej, red. K. Amielańczyk, Lublin 2009, s. 51-72.

4 Np. M. Jońca, Przestępstwo znieważenia grobu w rzymskim prawie karnym, Lublin 2013, passim. 
wościami interpretacyjnymi, jakie bez wątpienia dawały przepisy o charakterze ius cogens, nie pozwalając jurysprudencji na dokonywanie twórczej wykładni. Nie bez znaczenia jest także fakt, iż rzymskie ustawodawstwo karne było powiązane z systemem quaestiones perpetuae (w szczególności w okresie republiki) i prawdopodobnie interpretacja konkretnych regulacji prawnych powołujących stałe trybunały karne (quaestiones perpetuae) była konieczna jedynie w momencie ich początkowego okresu funkcjonowania (por. 17-18, gdzie Autorka podziela stanowisko V. Giuffré). W dalszej perspektywie atrakcyjność lex statuującej quaestio perpetua traciła znaczenie - z punktu widzenia jurysprudencji rzymskiej - i być może tutaj leży podstawowa przyczyna niechęci do gruntownego komentowania i prowadzenia analizy przepisów karnych. Co więcej, Autorka trafnie zauważyła (s. 18), iż dopiero w okresie pryncypatu wzrosło zainteresowanie jurysprudencji prawem karnym $\mathrm{w}$ ujęciu monograficznym (w tym okresie zaczynają powstawać dzieła De publicis iudiciis), wiążąc to z pozycją princepsa, który przejął praktycznie ciężar stanowienia norm o charakterze represyjnym. Zadaniem jurystów była raczej prezentacja tych rozwiązań, które na trwałe wpisywały się do prawa karnego i były efektem prawotwórczej działalności cesarza.

Pierwszy rozdział monografii (Indizi sull'esistenza di una 'parte generale' de publicis iudiciis nei manuali elementari di Paolo e di Fiorentino, s. 23-45) zawiera udaną próbę pokazania norm publicznoprawnych w dziele Paulusa (libri duo Institutionum), choć sama Autorka zauważyła, że analizowany tekst nie jest z pewnością oryginalną myślą tego jurysty. Okoliczność ta wpływa w znaczący sposób na interpretację, jednak wcale nie zniechęca to S. Pietrini do prowadzenia szczegółowej analizy. Gruntowna znajomość źródeł oraz literatury przedmiotu (por. przypisy na s. 26-28) pozwala jej na suwerenne panowanie nad problematyką. Co więcej, Autorka przedstawiając instytucję praeiudicum starała się poddać głębszej analizie źródła nie tylko prawnicze, ale i literackie, by w dalszej kolejności zająć się rozważaniem przestępstw, o których wzmiankował w swoim przekazie Paulus (s. 25). W celu pełnego przybliżenia punktu widzenia Paulusa, Autorka sięgnęła także do innych przekazów jurydycznych jego autorstwa, a także skonfrontowała je z przekazami nieprawniczymi (por. s. 29). Warto podkreślić, że S. Pietrini nie tylko stara się zidentyfikować problem badawczy, ale także próbuje go rozwiązać, prezentując stanowisko nauki $\mathrm{w}$ danej kwestii, a następnie przedstawiając własny punkt widzenia. Jest to szczególnie widoczne podczas ustalania autentyczności dzieła Paulusa (libri duo Institutionum) - zob. s. 32-34. Takie podejście do problemu badawczego zasługuje na wysoką notę, a tym samym potwierdza dojrzałość naukową Autorki, która nie stroni od budowania własnych hipotez i stawiania wniosków.

Druga część pierwszego rozdziału została poświęcona dziełu Florentinusa (libri Institutionum). Sam autor jest niezwykle zagadkową posta- 
cią ${ }^{5}$, bowiem bardzo trudno jest określić jego dorobek jurysprudencyjny, jak i epokę, w której tworzył. Przyjmuje się powszechnie, że działał on w czasach panowania dynastii Antoninów (por. s. 34). Centralny problem badawczy Autorki stanowi analiza tekstu Florentinusa D. 1, 1, 36, który został przedstawiony w szerszej perspektywie porównawczej na tle innych fragmentów z Digesta Iustiniani (s. 35-38). Stefania Pietrini podjęła przekonującą polemikę z reprezentantami doktryny, stojącymi na stanowisku, iż fragment Florentinusa należy łączyć z prawem prywatnym. Przekonywającym - ich zdaniem - argumentem było umieszczenie przez kompilatorów justyniańskich tego urywka z libri Institutionum w pierwszym tytule Digesta Iustiniani (De iustitia et iure). Autorka, przedstawiając swój tok rozumowania, starała się przekonać, że interpretacja tego fragmentu $\mathrm{w}$ połączeniu $\mathrm{z}$ innymi wyciągami z pism jurystów klasycznych daje zgoła odmienny rezultat (por. s. 37-45). Poczynione obserwacje na kanwie D. 1, 1, 3 potwierdzają hipotezę Autorki, iż w przypadku Instytucji Florentinusa możliwe jest wskazanie istnienia norm o charakterze ogólnym, właściwych dla prawa karnego (zob. s. 45). Warto podkreślić, że podczas prowadzenia rzeczowej polemiki Autorka sprawnie żonglowała argumentami, co w rezultacie pozwoliło jej wykazać trafność swej hipotezy.

$\mathrm{W}$ drugim rozdziale recenzowanej monografii (Il diritto penale nelle Instituzioni di Marciano, s. 46-127), który jest najobszerniejszy, Autorka skoncentrowała się na przybliżeniu pierwiastków prawnokarnych w monografii Marcianusa. Rozważania rozpoczęła od wyjaśnienia problemów związanych z datowaniem Institutiones Marcianusa (s. 49-52), by następnie przybliżyć zawartość pracy jurysty złożonej z 16 ksiąg (s. 52, 57). Warto zaznaczyć, że dzieło Marcianusa nie było $\mathrm{w}$ całości dedykowane prawu publicznemu ${ }^{7}$, bowiem większość ksiąg dotyczyła prawa prywatnego (księgi $1-9)^{8}$. Pozostałe z nich poświęcone

5 Zob. W. Litewski, Jurysprudencja rzymska, Kraków 2001, s. 141.

6 D. 1, 1, 3 (Florentinus libro primo institutionum): Ut vim atque iniuriam propulsemus: nam iure hoc evenit, ut quod quisque ob tutelam corporis sui fecerit, iure fecisse existimetur, et cum inter nos cognationem quandam natura constituit, consequens est hominem homini insidiari nefas esse. Warto wskazać, że Otto Lenel (Palingenesia Iuris Civilis, t. I, Lipsiae 1889, kol. 171), zestawiając ten fragment jurysty, powiązał go z prawem prywatnym. Co więcej, zasugerowany przez tego romanistę układ libri Institutionum Florentinusa w ogóle nie przewidywał elementów publicznoprawnych w jego dziele (por. ibidem, kol. 171, przyp. I). Nie można jednak nie zgodzić się z wywodami Autorki, która w przekonywający sposób dowodzi, że fragment ten może być traktowany w optyce prawa publicznego, a dokładnie prawa karnego - por. S. Pietrini, op. cit., s. 37-38.

7 Najwięcej odniesień do prawa publicznego można zaobserwować w księdze 14 Institutiones Marcianusa, gdzie jurysta szeroko odnosił się do poszczególnych leges iudiciorum publicorum - por. O. Lenel, op. cit., kol. 670-675.

8 Przygotowując swoje dzieło Marcianus położył największy nacisk na prawo spadkowe, które można odnaleźć w przeważającej liczbie zachowanych fragmentów w Digesta Iustiniani - zob. zestawienie dokonane przez O. Lenela (op. cit., kol. 657-667), które treściwo odpowiada księgom 4-9 w Institutiones Marcianusa. Poprzedzające księgi (tj. 1-3) odnoszą się do statusu prawnego, małżeństwa, podziału rzeczy, nabycia własności, opieki (tulela), czy też wyzwoleń niewolników - por. O. Lenel, op. cit., kol. 652-656. 
były komentowanym leges publicae (np. ad legem Corneliam de sicariis et veneficis, ad legem Iuliam repatundarum, etc.). Co więcej, Institutiones nie mogły byś traktowane jako typowy podręcznik do nauki prawa, ale mogły być również wykorzystywane przez biurokrację cesarską, raczej prowincjonalną, niż rezydującą w Italii (por. s. 54-58)9. Sięgnięcie do tej pracy przez reprezentantów codziennej praktyki prawa z pewnością ułatwiało wykonywanie powierzonych im obowiązków.

W dalszej części tego rozdziału Autorka zdecydowała się przedstawić Institutiones Marcianusa jako podstawowy podręcznik do nauki prawa (s. 60-80). Umieszczenie tego podrozdziału jest trochę dyskusyjne, gdyż treść, jaką odzwierciedla, w większości koncentruje się na prawie prywatnym (zob. s. 64-73), co niejako przeczy tytułowi całego rozdziału, dedykowanego prawu karnemu. Argumentu przemawiającego za utrzymaniem szerokiej prezentacji treści prywatnoprawnych można upatrywać, co zresztą podkreśla sama Autorka (por. s. 60), w tym, iż sam Justynian Wielki, zlecając przygotowanie swoich Institutiones, wzorował się na dziele Marcianusa ${ }^{10}$. Co więcej, szeroka charakterystyka podręcznika Marcianusa dokonana przez Autorkę miała dowieść i trzeba to jasno podkreślić - dowiodła - dydaktycznego aspektu tego dzieła.

Na podstawie fragmentów zachowanych w Digesta Iustiniani można zauważyć spory wkład tego jurysty w zakres treści kodyfikacji justyniańskiej, poczynając od zagadnień ogólnych (np. prawo osobowe), podziału rzeczy czy małżeństwa, a kończąc na prawie obligacyjnym. Warto jednak podkreślić, że Marcianus, omawiając na przykład problematykę podziału rzeczy w księdze 2 Institutiones ${ }^{11}$, nawiązywał do prawa karnego (por. D. 47, 12, 7). Fakt ten skrupulatnie wykorzystali kompilatorzy justyniańscy, umieszczając stosowny passus z jego dzieła $\mathrm{w}$ jednej z libri terribiles. Powyższe exemplum zostało podane przez samą Autorkę (por. s. 75) i wydaje się, że bardziej cenne byłoby pokazanie $\mathrm{w}$ tym podrozdziale takich związków między prawem prywatnym oraz prawem karnym. Samo referowanie treści prywatnoprawnych, jakże cennych i wartościowych, nie przybliża bowiem czytelnika do poznania nauczania prawa karnego w Institutiones Marcianusa. Bardziej zasadne byłoby więc zrezygnowanie $\mathrm{z}$ komentowanej jednostki redakcyjnej na rzecz szerszego przedstawienia ${ }^{12}$ relacji między prawem karnym a prawem prywatnym. Takie ujęcie materii potwierdziłoby, iż Rzymianie nie byli skłonni do precyzyjnej systematyki i odróżniania zagadnień prywatnoprawnych od publicznoprawnych.

9 Na marginesie warto wspomnieć, że Institutiones Marcianusa nie tylko były skierowane do administracji prowincjonalnej, ale także prawdopodobnie zostały zredagowane na prowincji, być może w okolicach Azji Mniejszej, skąd miał rzekomo pochodzić jurysta - zob. S. Pietrini, op. cit., s. 55.

10 Por. I. $4,3,1$.

11 Zob. O. Lenel, op. cit., kol. 656.

$12 \mathrm{~W}$ istocie Autorka dostrzega związki między prawem karnym a ius privatum (zob. s. 76-80), lecz są one podane w sposób wybiórczy i niepełny. 
Koleją kwestią, już ściśle skorelowaną z tytułem rozdziału drugiego, jest próba wykazania roli reskryptów cesarskich i samych leges iudiciourm publicorum dla redakcji Institutiones Marcianusa. Niestety, lektura tej części monografii też nie wypada do końca pozytywnie. Co prawda Autorka podkreśla doniosłą rolę reskryptów dla praktyki prawa, szczególnie na prowincji (por. s. 80 i nast.), ale nie pogłębia tej tezy na gruncie analizy Institutiones Marcianusa. Zamiast to uczynić, podkreśla rangę Sentencji Paulusa jako dzieła wykorzystywanego przez organy stosujące prawo. Obserwacje te są cenne, lecz wartościowsze byłoby pokazanie, na podstawie zachowanych fragmentów Institutiones Marcianusa (np. D. 48, 8, 1, 3, gdzie Marcianus powołuje się na reskrypt cesarza Hadriana $\left.{ }^{13}\right)$, czy jurysta starał się tylko podać treść konstytucji cesarskiej, czy też próbował ją komentować. Wydaje się, że ten drugi wariant był rzadko wykorzystywany, bowiem juryści rzymscy nie byli tak twórczy w zakresie prawa publicznego. Wynikało to przede wszystkim stąd, że prawo publiczne należało stosować ${ }^{14}$, a nie poddawać twórczej interpretacji, jak to było możliwe w przypadku prawa prywatnego. Pożądane więc było $\mathrm{w}$ ramach tego podrozdziału pokuszenie się o gruntowniejszą kwerendę źródłową i poddanie analizie tych fragmentów Institutiones Marcianusa, gdzie była mowa o reskryptach cesarskich. Takie przedstawienie materiału z pewnością poszerzyłoby wiedzę na temat roli i znaczenia dzieła tego jurysty w kształceniu studentów i kadry administracji cesarskiej.

Refleksje dotyczące prawa karnego w Institutiones Marcianusa byłyby niepełne, gdyby pominięto kwestię odbiorców tego dzieła. Tą problematyką Autorka zajęła się w kolejnym podrozdziale swej monografii (Gli studenti di Marciano, s. 89-103). Na samym początku słusznie stwierdziła, że w okresie cesarstwa doszło do gruntowej przebudowy wymiaru sprawiedliwości (s. 89). Było to wynikiem pojawienia się nowych urzędników (już od Augusta) wyposażonych $\mathrm{w}$ kompetencje jurysdykcyjne (np. praefectus Urbi, praefectus vigilum, etc.), wśród których istotna była ta dedykowana jurysdykcji karnej. Stąd też znajomość prawa karnego przez urzędników cesarskich była wręcz nieodzowna (por. s. 89 i nast.). Wspomnieć trzeba także o szerszym sięganiu do cognitio extra ordinem kosztem stałych (rzadziej już nadzwyczajnych - quaestiones extra ordinem) trybunałów karnych (quaestiones perpetuae). Te dwa tryby procedowania (cognitio extra ordinem oraz quaestiones perpetuae) wymagały zupełnie

13 Szerokie rozważania o reskryptach Hadriana prowadził K. Amielańczyk, Rzymskie prawo karne w reskryptach cesarza Hadriana, Lublin 2006, passim (rec. J. Zabłocki, „Zeszyty Prawnicze” 2007, nr 7.2, s. 355-363).

14 Rzymianie traktowali normy prawa publicznego w kategoriach ius cogens, co jasno wynika z następującego fragmentu, którego autorem był Papinian - D. 2, 14, 38 (Papinianus libro secundo quaestionum): Ius publicum privatorum pactis mutari non potest. Już chociażby z tego faktu można wywodzić niechęć jurystów rzymskich do dyskusji oraz interpretacji norm publicznoprawnych (w tym prawnokarnych). 
odmiennej znajomości norm prawnokarnych, co z kolei było dobrą okazją dla rzymskiej jurysprudencji, która mogła - poprzez pisanie dzieł o charakterze dydaktycznym - pomóc w przyswojeniu zagadnień z prawa karnego. Było to szczególnie pożądane $\mathrm{w}$ aparacie biurokratycznym, stąd też nie dziwi obserwacja Autorki, iż studentami podręcznika Marcianusa byli w pierwszej kolejności przedstawiciele cesarskiej biurokracji (s. 99-100), a także osoby parające się profesją odpowiadającą dzisiejszej adwokaturze. Taki zakres odbiorców, siłą rzeczy, wymuszał w konstrukcji Institutiones wyodrębnienie także wątków prywatnoprawnych (jak już wskazano wyżej - dominujących, zob. s. 101). Niezmiernie istotne było także poruszenie przez Autorkę nauki prawa w okresie cesarstwa, a w szczególności skoncentrowanie się na szkole prawa w Bejrucie ${ }^{15}$ (s. 95-99). Uwadze S. Pietrini nie umknęła także kwestia zależności między retorami a jurystami, czemu także dała wyraz na kartach tego podrozdziału. Pochylenie się nad tym problemem można traktować jako swoisty łącznik między kolejnym podrozdziałem, gdzie została przybliżona, w gruntowny i przekonywający sposób, relacja między retorami a jurysprudencją (s. 103-127). Na podstawie analizy źródeł nieprawniczych (w szczególności Seneki, Tacyta i obszernie Ps.-Kwintyliana) oraz stosownych fragmentów z Institutiones Marcianusa Autorka pokazała zakres zainteresowań prawnokarnych obu grup (np. zabójstwo, iniuria, trucicielstwo, przestępstwa na tle seksualnym - stuprum oraz adulterium, czy wreszcie patria potestas). Pobieżna lektura przytoczonych powyżej zagadnień prawnokarnych - wspólnych dla jurystów i retorów - wskazuje, że obie grupy nie parały się marginalną problematyką, a wręcz przeciwnie koncentrowały się na zagadnieniach najistotniejszych. Rozważania prowadzone w tym podrozdziale odbywają się na zasadzie poszukiwania paralelnych zainteresowań retorów i jurystów, i poddania ich analizie naukowej. Jest to pożądany kierunek badaczy, gdyż potwierdza on konieczność sięgnięcia przez romanistykę do źródeł pozaprawnych, w celu szerszego ukazania rozważanego zagadnienia. Co więcej, źródła literackie, czytane oczywiście z zachowaniem ostrożności, mogą poświadczać ówczesną praktykę prawną, niezwykle trudną do uchwycenia w źródłach jurydycznych.

Czytelnik poszukujący $\mathrm{w}$ tym rozdziale głębszych rozważań z prawa karnego $\mathrm{w}$ przedmiocie np. form stadialnych przestępstwa, winy, dyrektyw wy-

15 Ta problematyka jest obiektem szerokiego i wielowątkowego zainteresowania P. Sadowskiego zob. P. Sadowski, Szkoła prawa w Bejrucie w świetle Vita Severi Zachariasza Scholastyka, [w:] Romanitas et christianitas. Stanislao Płodzień (1913-1962) in memoriam, red. A. Dębiński, S. Jóźwiak, Lublin 2008, s. 199-210; idem, Ideały społeczne szkoły prawa w Bejrucie (III-VI w. n.e.), [w:] Społeczeństwo a władza. Ustrój, prawo, idee, red. J. Przygodzki, M. J. Ptak, Wrocław 2010, s. 173-184; idem, Nauczanie prawa w Bejrucie a trzęsienia ziemi w Libanie w VI w. n.e., [w:] Idea wolności w ujęciu historycznym i prawnym. Wybrane zagadnienia, red. E. Kozerska, P. Sadowski, A. Szymański, Toruń 2010, s. 65-76; idem, Profesorowie szkoły prawa w Bejrucie $w$ V w. n.e., [w:] Wybrane problemy nauki i nauczania prawa, red. E. Kozerska, P. Sadowski, A. Szymański, Opole 2010, s. 103-120; idem, Szkoła prawa w Bejrucie w świetle mów i listów Libaniusza, „Studia Prawnoustrojowe” 2010, nr 12, s. 203-218. 
miaru kary etc. może poczuć lekki niedosyt. Kwestie te są co prawda trudne do uchwycenia, gdyż sami juryści stronili od definiowania pojęć i instytucji prawnych $^{16}$. Wydaje się jednak, że dorobek prawnokarny Marcianusa, przekazany w Digesta Iustiniani ${ }^{17}$, dawał dość solidną podstawę do zmierzenia się z tym zagadnieniem. Pochylenie się nad sygnalizowanymi kwestiami (choć z nazwy nieznanymi starożytnym Rzymianom) i chociażby próba ich nakreślenia, pozwoliłoby na poszerzenie kręgu odbiorców monografii. Z pewnością badacze współczesnego prawa karnego mogliby wtedy znaleźć zalążki instytucji prawnych, które obecnie są fundamentem teraźniejszych kodyfikacji karnych.

Należy zauważyć, że tak obszerny i wielowątkowy rozdział (s. 47-127) powinien chyba zakończyć się syntetycznym podsumowaniem, wieńczącym rezultaty badań Autorki, które nie musiałoby być wyodrębnione redakcyjnie (choć to byłoby optymalne). Próżno jest jednak poszukiwać go w recenzowanej dysertacji. Szkoda, bowiem podsumowanie badań przez Autorkę pozwoliłoby sprawnie śledzić jej tok rozważań i byłoby dobrym łącznikiem przed lekturą kolejnego rozdziału monografii.

Ostatni rozdział (Il titolo 18 del quarto libro delle Istituzioni di Giustiniano, s. 129-162) może tylko z pozoru nie łączyć się z tytułem recenzowanej monografii. Zamiarem Autorki było bowiem wykazanie, jaki wpływ na Instytucje Justyniana, w szczególności w zakresie systematyki tytułu 18 księgi 4 wywarły Institutiones Marcianusa. Prowadzone w tym rozdziale rozważania są spójne i nie budzą zastrzeżeń. Autorka paralelnie podaje fragment źródłowy z Instytucji Justyniana i następnie wskazuje, że swą treść zawdzięcza inspiracjom z dzieła Marcianusa, co ilustruje stosownym passusem z Institutiones tego jurysty (zob. np. s. 136, 143-147 etc.). Zdarza się, że Autorka do ukazania szerszego kontekstu rozważań musiała sięgnąć do innych źródeł niż autorstwa Marcianusa (np. s. 135-136, 148 etc.). Nie należy tego poczytywać jako zarzutu, a wręcz przeciwnie - dzięki temu czytelnik otrzymał szerszy

16 Por. W. Litewski, Podstawowe wartości prawa rzymskiego, Kraków 2001, s. 177.

17 Analiza fragmentów autorstwa Marcianusa - D. 48, 6, 3, 3 oraz 5 w połączeniu z D. 47, 9, 11 - byłaby wartościowym przyczynkiem do ukazania odpowiedzialności podpalacza (incendiarius) w zależności od ustalenia stopnia jego winy. Podobnie na podstawie sygnalizowanego już wyżej fragmentu D. 48, 8, 1, 3 można by wykazać, czy Marcianus cytował tu jedynie reskrypt Hadriana, gdzie była mowa o usiłowaniu zabójstwa (oraz innych, używając współczesnej terminologii właściwej naukom penalnym, formach stadialnych przestępstwa), czy może był to jego wkład w szersze pojmowanie treści konstytucji cesarskiej. Wydaje się też, że dobry materiał badawczy mogły stanowić rozważania Marcianusa o karze relegatio - zob. D. 48, 19, 4; D. 48, 22, 2; D. 48, 22, 4, których lektura pozwala wykazać, że jurysta - szczególnie w pierwszym fragmencie - dawał wskazówki co do wymiaru tej kary (skierowane być może, w pierwszej kolejności, do podmiotów kompetentnych w zakresie wymiaru sprawiedliwości), które mogły być jego twórczą interpretacją bądź przytoczeniem treści reskryptu cesarskiego (rzadziej innej formy konstytucji cesarskiej). Są to jedynie przykładowo podane źródła, które można było poddać gruntowniejszej analizie, choć nie można Autorce zarzucić ich nieznajomości - zob. s. 130 przyp. 2. 
kontekst źródłowy, odzwierciedlający problem badawczy, nad jakim pochylała się Autorka.

Rozważania prowadzone przez S. Pietrini dowodzą szerokich inspiracji, jakie czerpał cesarz Justynian z Institutiones Marcianusa. Odnosi się to przede wszystkim do układu problemowego Instytucji Justyniana (szczegółowo, s. 135-157). Praktycznie jest on wierną kopią materii prawnokarnej, jaką można śledzić w zachowanych fragmentach (z inskrypcją z Institutiones) w Digesta Iustiniani. Wyjątkiem, który skrupulatnie odnotowała Autorka (s. 157-158), jest jedynie wspomnienie w Instytucjach Justyniana (I. 18,4,11) o niektórych leges iudiciorum publicorum (lex Iulia de ambitu, lex Iulia repetundarum, lex Iulia de annona), którymi zajmował się Marcianus (nie tylko w Institutiones).

Konkluzja, do jakiej doprowadziły Autorkę prowadzone badania, jest jednoznaczna. Zasługi Marcianusa dla rozwoju nauki prawa są niekwestionowane, a to, co wyróżnia tego jurystę, to poświęcenie - $\mathrm{w}$ jego podręczniku - miejsca prawu karnemu (por. s. 160). Nie ma żadnych przeszkód, aby tego spostrzeżenia nie podzielić.

Rozważania prowadzone przez S. Pietrini na kartach całej monografii są przekonywające i rzeczowo dokumentowane źródłami i literaturą przedmiotu. Szkoda tylko, że Autorka zrezygnowała w pracy z zakończenia. Syntetyczne zebranie w jednym miejscu obserwacji i spostrzeżeń było pożądane i z pewnością ułatwiłoby czytelnikowi lekturę wniosków, do jakich doszła. Choć monografia zawiera jedynie trzy rozdziały, to materia badawcza, bardzo rozległa, powinna być $\mathrm{z}$ metodologicznego punktu widzenia zamknięta przytoczeniem finalnych konkluzji. Brak ich prezentacji w jednym miejscu należy poczytywać jako mankament pracy.

Podniesione krytyczne uwagi nie deprecjonują tej wartościowej monografii. Trzeba przyznać, że Autorka prawidłowo określiła problemy badawcze i konsekwentnie dążyła do ich rozstrzygnięcia. Wykorzystała do tego celu w umiejętny sposób zachowane źródła oraz literaturę przedmiotu. Stąd też jej argumentacja i wnioski są przekonywające oraz gruntownie osadzone w materiale badawczym.

Warto podkreślić, że recenzowana monografia stanowi wstęp do dalszych badań nad nauczaniem prawa karnego $\mathrm{w}$ antyku, które niewątpliwe należy kontynuować. 